\title{
Exploring the Nature of Whistle Blowing in Organizations in Asia: An Integrative Perspective
}

\author{
Dodi Wirawan IRAWANTO ${ }^{1}$, Khusnul Rofida NOVIANTI²
}

Received: July 03, 2020 Revised: September 19, 2020 Accepted: October 05, 2020

\begin{abstract}
This paper aims to synthesize and identified several constraints of the research literature about whistleblowing and its impact on the organizations from the human resource and organizational behavior point of view. The importance of study concerning whistleblowing is an important trend in this today fraudulent world, however to our knowledge an integrative review in this sense is limited. By looking at the impact of whistleblowing act in collectivist culture, especially from the Asian perspective would give an impact to the development of the studies in the future. This review using an integrative review with the distribution of databases including Sciencedirect, EBSCO, JSTOR and soon using several terms including whistleblowing and collectivist of research published during 2003 to 2018. Thirty five papers were identified, analyzed, and capturing data of research located in several Asian countries such as China, India, Indonesia, Malaysia, South Korea, Thailand and Turkey. The findings of this review reveals that despite a positive trend of whistleblowing research in collectivist culture, the importance to increase human resource and organizational behavior aspects also lead to positive ethic climate in organization. Human resource and organizational behavior aspects to be found have a significance role in creating ethical culture in the organization.
\end{abstract}

Keywords: Collectivist, Ethical Climate, Integrative Review, Whistleblowing

JEL Classification Code: D23, D63, M20, O15

\section{Introduction}

Issues regarding whistleblowing have become a global concern over the last few decades (ACFE, 2019). Scholars in the fraud area such as Brennan and Kelly (2007) has fundamentally define whistleblowing as a disclosure made by employees or former employees of an organization of an illegal, immoral, or legal legitimate practice under the control of their leaders to individuals or organizations that can have the effect of remedial actions. Key issues such as immoral acts have been captured by many HR

${ }^{1}$ First Author and Corresponding Author. Associate Professor, Department of Management, Faculty of Economics and Business, Brawijaya University, Indonesia [Postal Address: Veteran Street Ketawanggede, Lowokwaru, Malang, East Java, 65145, Indonesia] Email: dodi.wi@ub.ac.id

${ }^{2}$ Lecturer, Department of Management, Faculty of Economics and Business, University of Muhammadiyah Malang, Indonesia. Email: khusnulrofida@umm.ac.id

(c) Copyright: The Author(s)

This is an Open Access article distributed under the terms of the Creative Commons Attribution Non-Commercial License (https://creativecommons.org/licenses/by-nc/4.0/) which permits unrestricted non-commercial use, distribution, and reproduction in any medium, provided the original work is properly cited. researchers in light of their impact on organizational life (Lukakcs et al., 2012). In increasing organizational performance, reports from whistleblowers have proven to be more effective in exposing fraud compared to other methods such as internal audit, internal control and external audit (Robinson, Robertson, \& Curtis, 2012). This trend in line with the Report to the Nation published by the Association of Certified Fraud Examiners (ACFE) every two years (most recently in 2018) which always puts un-ethical working behavior in the top ranking of fraud disclosure sources. Understanding the effectiveness of whistleblowing then triggers various organizations to start proactively detecting fraud by implementing a hotline whistleblowing system through various means of organizational activities, such as in the high context culture that implies unless commitment in engaging with the whistleblowing practices (Cheng, Karim, \& Lin, 2015).

Reporting wrongdoings in some culture may be seen as a positive attitudes, whereas in other culture such as collectivist culture it may be referred to an unethical culture results that many individuals who see irregularities but choose not to report them because the ethical, cultural and work behavior values that develop within the organization 
are not supportive (Chordiya et al., 2019). Research in Asian countries (i.e., Suyatno, Amstrong, \& Thomas, 2017; Ab Ghani, Galbreath, \& Evans, 2011) often leaders of government agencies who are supposed to be pioneers in the implementation of ethical values actually do not support it. This resulted in very few whistleblowers who had the courage to reveal the corruption cases that he met with the public expectations. The prevailing culture in most Asian countries emphasizes togetherness and brotherhood, making working relationships between individuals in an organization in these regions tend to avoid conflicts between people. As result, whistleblowers who dare to disclose deviations that they know with the risk of facing conflict with other parties will rarely appear.

Research in the area of fraud that implies the organizational effectiveness is limited, but there are still questions about what factors can influence the intention of employees to carry out internal whistleblowing within the scope of organization in the collectivist culture on how important the role of these factors is. Therefore, this review aims to identify the nature of whistleblowing acts in the organization that lensed from high context culture (i. e., Collectivist culture) in Asian countries. Review of research done in Asia ranging from 2003 to 2018 that stressed the impact of collectivist culture in an attempt to practices whistleblowing systems in organizations that impact HR dimensions. The review also highlights what HR dimensions could positively associate with the whistleblowing acts.

\section{Literature Review}

Near and Miceli (1985) define whistleblowing as disclosure by the organizational member (former or current) of illegal, immoral or illegitimate practices under the control, to person or organization that may be able to affect the organization. Organizations will suffer losses if they fail to create conducive conditions for their members to disclose fraud and wrongdoings from the internal aspect. The organization is expected to be able to create a conducive environment in order to encourage employees against all fraud, wrongdoings, and corruption that occur in an organization (Nurhidayat \& Kusumasari, 2018).

Whistleblowing becomes a behavior related to ethical issues within the organization. Ethical values that form the basis of whistleblowing behavior are the values of integrity, transparency, and protection against disclosure of wrongdoing and fraud. Whistleblowing can be reported internally, externally and anonymously by whistleblowers in connection with existing cheating practices. Internal whistleblowing indicates that an employee reports the wrongdoing action within the organization. This can provide an opportunity for the organization to correct its decision or unethical practices. Internal whistleblowing encouraged by organization and leader as the role model. However, external whistleblowing like disclosing unethical practices outside the organization or to the public can damage the organization's image. External whistleblowing indicates bringing internal wrongdoing into external agencies like media. The research found that mostly whistleblower prefer to report externally with anonym identity. Magnus and Visweran (2005) revealed that whistleblowing is unusual behavior, an undesirable thing that occurs in organizations and becomes a problem related to ethical behavior that can arise in both public and private organizations. Knowing that there are fraud, wrongdoing, and immoral behavior and decided to report it as a whistleblower is not easy. The courageous decision to report fraud or wrongdoing is a complex phenomenon.

The whistleblowing phenomenon is one example in the Prosocial Behavior Theory that is widely used by many researchers such as Ahmad et al. (2012), and Miceli and Near (1988). Prosocial behavior is a behavior intended to benefit other persons (Latan et al., 2019). This theory suggests that members of an organization will carry out efforts or actions against members that can endanger the organization and also its members, one of which is fraud, wrongdoing or malpractice to protect the interests and welfare of the organization and related stakeholders. Although whistleblowing is one of the important things in preventing wrongdoing within the organization, many organizations do not agree with this whistleblowing behavior. In the minds of employees, whistleblowing takes big risks, negative appraisal, job loss, and even ongoing persecution of the whistleblower (Zhang et al., 2009) and they prefer to keep silent. Several studies indicated that whistleblowing intention is the desire to obtain financial incentives (Latan et al., 2018a). This whistleblowing behavior is closely related to one's intention in reporting fraud and accepting all kinds of risks. Whistleblowing acts can be classified as a pro-social empowered behavior driven by voluntary and duty-related disclosures of wrongdoing.

\section{Research Methods and Materials}

For the purposes of this study, an integrative review approach from the HRD best practices which is defined as a summary of the literature in certain contexts or content areas, where research is summarized, analyzed, and overall conclusions are drawn (Torraco, 2005) is used. In the HRM literature, reviewing literature relates to the impact of culture dimensions, an integrative review is considered appropriate for the purposes of current review because it plays a greater role in evidence-based practice and indeed can expand the determinants aspects of the whistleblowing problem within the HRM coverage (VomBrocke et al., 2009). That is, 
too considered appropriate because it is an approach where the review considers a combination of various methodologies. To reach the goal integrative review the following steps adapted from Beyea and Nichll (1998).

To reach optimum inclusion of study review, this paper using the identification database searched and list of inclusion/exception, synthesis and assessment the overall quality of each paper has been taken and does not exclude paper based on quality assessment based on the researches justification. In order to search strategy, google scholar search engine was undertaken as the first gate to enter the world of whistleblowing by using the keywords "whistleblow*" combined with "collectivist*". The second gate to gain the quality data is to refer with the credible all scholarly databases including EBSCO, Sciencedirect, Elsevier, Emeraldinsight, JSTOR and soon. To reach optimum search several inclusion/ exclusion criteria were applied not to limit includes : (1) published between 2003 and 2019 in English, (2) Peerreviewed publication; (3) focus on whistleblowing in any type organizations which observed the HRM variables; and (4) papers drawing on a diverse combination of methodology was included in the review.

\section{Results and Discussion}

A total of 35 papers were included in the review. The papers are drawn from several research studies about whistleblowing in collectivist culture. Papers were from China (7), Malaysia (7), Indonesia (7), South Korea (5), India (5), Turkey (3) and Thailand (1) highlighting the cultural interest in collectivist culture and whistleblowing intention and can be seen in Table 1:

The surveys mainly using quantitative approach (32 papers) and the other using qualitative (3) and mix methods approach (3). Some of the paper using experimental design for their data collection method. To appraise the quality of both the quantitative and qualitative research methods in the papers, we are using The Critical Appraisal Skills Programme (CASP, 2014) qualitative checklist. The qualitative studies should be met all the criteria in the checklist (Table 2). There are few appraisal tools for cross-sectional survey studies or validated guidelina in this study (Bennett et al., 2011). We also using Bowling's (2009) quantitative checklist in this papers to make some appraisal of the quantitative studies to enable some comparisons accross research in Table 3.

Table 1: Summary of Finding

\begin{tabular}{|c|c|c|}
\hline HR/OB Theme & Finding & Studies \\
\hline Locus of control & $\begin{array}{l}\text { Locul of control plays an important roles in mediating the relationship } \\
\text { between ethical judgement and whistleblowing }\end{array}$ & Chiu (2003) \\
\hline Authentic leadership & $\begin{array}{l}\text { Authentic leadership is positively related to internal whistleblowing, } \\
\text { authentic leadership has an indirect effect on internal whistleblowing } \\
\text { intention through psychological safety }\end{array}$ & $\begin{array}{l}\text { Liu, Liao, \& Wei } \\
\text { (2015), Anugerah, } \\
\text { Abdillah, \& Anita } \\
\text { (2018) }\end{array}$ \\
\hline Personal Trait & $\begin{array}{l}\text { The principle climate adhered to by internal auditor more outstanding than } \\
\text { egoism and benevolence cimate }\end{array}$ & Ahmad et al. (2014) \\
\hline Well-being & $\begin{array}{l}\text { The protection of whistleblowers is needed, dismissed the } \\
\text { whistleblowers experienced higher level of negative effect was } \\
\text { prominent factor in all of the negative health effect types }\end{array}$ & Park \& Lewis (2018) \\
\hline $\begin{array}{l}\text { Cultural Orientation } \\
\text { (National Culture) } \\
\text { Individualism vs } \\
\text { Collectivism }\end{array}$ & $\begin{array}{l}\text { - Nationality was a significant factor on whistleblowing intention } \\
\text { - Collectivism culture (confucian) were significantly positive in part, but } \\
\text { overall were inconsistent in the matter of whistleblowing intention } \\
\text { - External and anonymous whistleblowing have a significant relationship } \\
\text { - Companies should create a culture that encourages employees to } \\
\text { ask questions early and pick out unethical or illegal practices through } \\
\text { conduct training, provies financial incentives and allow anonymous } \\
\text { whistleblowing } \\
\text { - Thai culture influenced subjective norms for whistleblowing } \\
\text { - Sociocultural dynamics impacting the emergence, persistence } \\
\text { and recognition of wrongdoing, the decision to blow the whistle, } \\
\text { engagement in whistleblowing and the outcomes of whistleblowing } \\
\text { encompass social relationships, power distribution, materialistic } \\
\text { considerations, sense of propriety and fairness, public orientation and } \\
\text { ideological leanings. }\end{array}$ & $\begin{array}{l}\text { Park, Blenkinsopp, } \\
\text { Oktem \& } \\
\text { Omurgonulsen } \\
\text { (2008), } \\
\text { Park, Rehg, \& Lee } \\
\text { (2005), } \\
\text { Nayir \& Herzig } \\
\text { (2012), } \\
\text { Rachagan \& } \\
\text { Kuppusamy (2013), } \\
\text { Trongmateerut \& } \\
\text { Sweeney (2013), } \\
\text { D'Cruz \& Bjørkelo } \\
\text { (2015), } \\
\text { Dhamija \& Rai (2018) }\end{array}$ \\
\hline
\end{tabular}


Table 1: Continued

\begin{tabular}{|c|c|c|}
\hline Ethical Culture & $\begin{array}{l}\text { - General sense of morality was the most important factor to encourage } \\
\text { whistle-blowing. } \\
\text { - Guanxi (personal relationship) fear of retaliation and media coverage may } \\
\text { discourage whistleblowing in Chinese society } \\
\text { - Social desirability response bias existed } \\
\text { - There are no differences about accounting professionals whistleblowing } \\
\text { behavior in terms of their demographic characteristics (working } \\
\text { circumstances, total tenure, age, membership and number of customers) } \\
\text { with the exception of gender and age variables } \\
\text { - Promoter shareholding, proportion of independent directors and specific } \\
\text { positions like chief ethical officer influence disclosure of whistleblowing } \\
\text { policies } \\
\text { - Human and ethical culture, policy, legal protection, organizational structure } \\
\text { as well as procedures and process in accordance to Indonesia's specific } \\
\text { characteristics affect whistleblowing } \\
\text { - Public sector employees are more idealistic and less inclined to } \\
\text { whistleblow externally and anonymously, however private sector } \\
\text { employees are more relativistic } \\
\text { - Perceived seriousness of threats reduces individuals' intention to blow the } \\
\text { whistle. }\end{array}$ & $\begin{array}{l}\text { Hwang, Staley, } \\
\text { Chen, \& Lan (2008), } \\
\text { Ahmad et al. (2014), } \\
\text { Erkmen, Çalişkan, \& } \\
\text { Esen (2014), } \\
\text { Agnihotri \& } \\
\text { Bhattacharya } \\
\text { (2015), } \\
\text { Nurhidayat \& } \\
\text { Kusumasari (2016), } \\
\text { Nayır, Rehg, \& Asa } \\
\text { (2018), } \\
\text { Latan, Jabbour, \& } \\
\text { Jabbour (2019) }\end{array}$ \\
\hline $\begin{array}{l}\text { Organizational } \\
\text { Commitment }\end{array}$ & $\begin{array}{l}\text { - Attitude, subjective norm, and perceived behavioral control had significantly } \\
\text { positive main effects on internal whistleblowing intentions, but for external } \\
\text { whistleblowing intentions only subjective norm was significant } \\
\text { - There is no direct effect of the whistleblower audit quality and no indirect } \\
\text { effect of ethics, commitment and independence to audit quality through the } \\
\text { intermediary of whistleblower }\end{array}$ & $\begin{array}{l}\text { Park \& Blenkinsopp } \\
\text { (2009), } \\
\text { Syamsudin } \\
(2017)\end{array}$ \\
\hline $\begin{array}{l}\text { Organizational } \\
\text { Ethical Culture }\end{array}$ & $\begin{array}{l}\text { - Organizational culture affects the whistleblowing judgment and } \\
\text { whistleblowing intention } \\
\text { - Gender did not have any significant influence on the likelihood to whistle } \\
\text { blow, different with job position that have significant influence. } \\
\text { - The retaliation from the co-workers and the organization is the top } \\
\text { influencing factors that stop whistle blower from reporting the malpractices. }\end{array}$ & $\begin{array}{l}\text { Zhang, Chiu, \& Wei } \\
(2009), \\
\text { Anuar et al. } \\
(2019)\end{array}$ \\
\hline Ethical Leadership & $\begin{array}{l}\text { - Not only do ethical leadership and LMX predict whistle blowing, but these } \\
\text { relationships get moderated by the moral intensity of the issue as well } \\
\text { - Individual factors (religiosity and ethical values) significantly contribute to } \\
\text { fraud reduction whereas both organizational factors (ethical leadership } \\
\text { and whistleblowing practices) does not significantly contribute to employee } \\
\text { fraud mitigation } \\
\text { - moral courage is found to moderate the effect of employee-perceived } \\
\text { organizational politics on internal whistleblowing }\end{array}$ & $\begin{array}{l}\text { Bhal \& Dadhich } \\
(2011) \\
\text { Said et al. (2017), } \\
\text { Anuar, Saiful, \& } \\
\text { Puteh } \\
(2017) \text {, } \\
\text { Cheng, Bai, \& Yang } \\
(2019)\end{array}$ \\
\hline $\begin{array}{l}\text { Interpersonal } \\
\text { Relationship }\end{array}$ & $\begin{array}{l}\text { - The impact of workplace relationship on whistle-blowing intention would } \\
\text { not be simply linear but curvilinier when the person group fit and person- } \\
\text { supervisor fit become very high, the intention to whistlebow dwindles. }\end{array}$ & $\begin{array}{l}\text { Kyu Wang, Fu, \& } \\
\text { Yang } \\
(2018)\end{array}$ \\
\hline $\begin{array}{l}\text { Job Satisfaction, } \\
\text { Fair Treatment, } \\
\text { Performance } \\
\text { Appraisal, } \\
\text { Compensation }\end{array}$ & $\begin{array}{l}\text { - Fair treatment is statistically significant and positively related to the } \\
\text { whistleblowing practice. } \\
\text { - If employees perceive that the organization provides fair treatment } \\
\text { in terms of career advancement, training, performance appraisal, job } \\
\text { assignment, and pay increases, they would tend to report wrongdoing } \\
\text { activities to protect the image of the organization } \\
\text { - Financial incentives are the most significant predictor of auditors } \\
\text { intention to blow the whistle in Indonesia }\end{array}$ & $\begin{array}{l}\text { Said, Alam, } \\
\text { Mohamed, \& } \\
\text { Rafidi (2017), } \\
\text { Latan, Ringle, \& } \\
\text { Jabbour (2018) }\end{array}$ \\
\hline
\end{tabular}


Table 1: Continued

\begin{tabular}{|c|c|c|}
\hline $\begin{array}{l}\text { Organizational } \\
\text { Support }\end{array}$ & $\begin{array}{l}\text { - Colleague and organizational support have the biggest effect of } \\
\text { whistleblowing intention } \\
\text { - A proper communication channel needed for reporting wrongoings } \\
\text { internally } \\
\text { - Internal auditors are more likely to blow the whistle than external } \\
\text { auditors; and reporting wrongdoing internally and anonymously are } \\
\text { the preferred way of professional accountants to blow the whistle in } \\
\text { Indonesia. }\end{array}$ & $\begin{array}{l}\text { Chang, Wilding, \& } \\
\text { Shin } \\
\text { (2017), } \\
\text { Chaudary, Priya, \& } \\
\text { Phoolka (2017), } \\
\text { Latan et al. (2018), } \\
\text { Latan, Jabbour, \& } \\
\text { Jabbour (2019) }\end{array}$ \\
\hline
\end{tabular}

Source: own secondary data

Table 2: Appraisal Summary

\begin{tabular}{|c|c|c|c|}
\hline \multicolumn{2}{|c|}{ Checklist Used } & Yes & No \\
\hline \multicolumn{4}{|c|}{ Quantitative Survey Studies Critical Appraisal Checklist*, N=32 } \\
\hline 1 & Aims and objectives clearly stated & 32 & \\
\hline 2 & Design adequately describes & 32 & \\
\hline 3 & Questionnaire described (tools used, core items, scoring of items) & 23 & 9 \\
\hline 4 & Instrument used tested for reliability and validity & 17 & 15 \\
\hline 5 & $\begin{array}{l}\text { Sample described (response rate, number, and respondent } \\
\text { characteristics) }\end{array}$ & 25 & 7 \\
\hline 6 & Ethical considerations & 10 & 22 \\
\hline 7 & Results reported and clear & 30 & 2 \\
\hline 8 & Limitations reported & 24 & 8 \\
\hline 9 & Conclusions do not go beyond limit of data and results & 24 & 8 \\
\hline 10 & Findings able to be generalized & 20 & 12 \\
\hline 11 & Implication discussed & 26 & 16 \\
\hline \multicolumn{4}{|c|}{ Qulitative Survey Studies Critical Appraisal Checklist*, N=3 } \\
\hline 1 & Clear statement of the aims of the research & 3 & \\
\hline 2 & Qualitative methodology appropiate & 3 & \\
\hline 3 & Research design appropiate to address the aims of the research & 3 & \\
\hline 4 & $\begin{array}{l}\text { The recruitment strategy appropiate to address the aims of the } \\
\text { research }\end{array}$ & 3 & \\
\hline 5 & Data collected in a way that addresses the research issues & 3 & \\
\hline 6 & $\begin{array}{l}\text { Relationship between researcher and participants been } \\
\text { adequately considered }\end{array}$ & 2 & 1 \\
\hline 7 & Ethical issues been taken into consideration & 2 & 1 \\
\hline 8 & Data analysis sufficiently rigorous & 3 & \\
\hline 9 & Clear statement of findings & 3 & \\
\hline
\end{tabular}

Note: *adapted from Bowling (2009), ${ }^{* *}$ CASP (2014). 
Table 3: Surveys Studies Critical Appraisal Checlist

\begin{tabular}{|c|c|c|c|c|c|c|c|c|}
\hline Author & Instrument & Aims & $\begin{array}{l}\text { Instrument } \\
\text { tested }\end{array}$ & Sample & Ethics & $\begin{array}{l}\text { Result } \\
\text { Clarity }\end{array}$ & $\begin{array}{c}\text { Practical } \\
\text { Implication }\end{array}$ & Conclusion \\
\hline Chiu (2003) & Yes & $\sqrt{ }$ & $\sqrt{ }$ & $\sqrt{ }$ & $\sqrt{ }$ & $\sqrt{ }$ & - & $\sqrt{ }$ \\
\hline $\begin{array}{l}\text { Park, Rehg, \& } \\
\text { Lee (2005) }\end{array}$ & Yes & $\sqrt{ }$ & $\sqrt{ }$ & $\sqrt{ }$ & $\sqrt{ }$ & $\sqrt{ }$ & - & - \\
\hline $\begin{array}{l}\text { Park, } \\
\text { Blenkinsopp, } \\
\text { Oktem \& } \\
\text { Omurgonulsen } \\
(2008)\end{array}$ & Yes & $\sqrt{ }$ & $\sqrt{ }$ & $\sqrt{ }$ & $\sqrt{ }$ & $\sqrt{ }$ & $\sqrt{ }$ & - \\
\hline $\begin{array}{l}\text { Hwang, Staley, } \\
\text { Chen, \& Lan } \\
(2008)\end{array}$ & Yes & $\sqrt{ }$ & - & $\sqrt{ }$ & - & $\sqrt{ }$ & $\sqrt{ }$ & $\sqrt{ }$ \\
\hline $\begin{array}{l}\text { Park \& Blenkin- } \\
\text { sopp (2009) }\end{array}$ & Yes & $\sqrt{ }$ & - & $\sqrt{ }$ & - & $\sqrt{ }$ & $\sqrt{ }$ & $\sqrt{ }$ \\
\hline $\begin{array}{l}\text { Zhang, Chiu, \& } \\
\text { Wei (2009) }\end{array}$ & Yes & $\sqrt{ }$ & - & - & - & $\sqrt{ }$ & $\sqrt{ }$ & - \\
\hline $\begin{array}{l}\text { Zhang, Chiu, \& } \\
\text { Wei (2009) }\end{array}$ & No & $\sqrt{ }$ & $\sqrt{ }$ & $\sqrt{ }$ & - & $\sqrt{ }$ & $\sqrt{ }$ & $\sqrt{ }$ \\
\hline $\begin{array}{l}\text { Bhal \& Dadhich } \\
(2011)\end{array}$ & Yes & $\sqrt{ }$ & $\sqrt{ }$ & - & - & $\sqrt{ }$ & $\sqrt{ }$ & $\sqrt{ }$ \\
\hline $\begin{array}{l}\text { Nayir \& Herzig } \\
(2012)\end{array}$ & Yes & $\sqrt{ }$ & - & $\sqrt{ }$ & - & $\sqrt{ }$ & $\sqrt{ }$ & $\sqrt{ }$ \\
\hline $\begin{array}{l}\text { Trongmateerut \& } \\
\text { Sweeney (2013) }\end{array}$ & Yes & $\sqrt{ }$ & $\sqrt{ }$ & $\sqrt{ }$ & - & $\sqrt{ }$ & $\sqrt{ }$ & $\sqrt{ }$ \\
\hline $\begin{array}{l}\text { Ahmad et al. } \\
(2014)\end{array}$ & No & $\sqrt{ }$ & $\sqrt{ }$ & - & - & - & - & $\sqrt{ }$ \\
\hline $\begin{array}{l}\text { Ahmad et al. } \\
(2014)\end{array}$ & Yes & $\sqrt{ }$ & $\sqrt{ }$ & - & $\sqrt{ }$ & - & $\sqrt{ }$ & - \\
\hline $\begin{array}{l}\text { Erkmen, } \\
\text { Çalişkan, \& Esen } \\
(2014)\end{array}$ & No & $\sqrt{ }$ & - & $\sqrt{ }$ & - & $\sqrt{ }$ & $\sqrt{ }$ & $\sqrt{ }$ \\
\hline $\begin{array}{l}\text { Agnihotri \& } \\
\text { Bhattacharya } \\
(2015)\end{array}$ & Yes & $\sqrt{ }$ & - & - & - & $\sqrt{ }$ & - & $\sqrt{ }$ \\
\hline $\begin{array}{l}\text { Liu, Liao, \& Wei } \\
(2015)\end{array}$ & No & $\sqrt{ }$ & - & $\sqrt{ }$ & - & $\sqrt{ }$ & $\sqrt{ }$ & $\sqrt{ }$ \\
\hline $\begin{array}{l}\text { Syamsudin } \\
(2017)\end{array}$ & No & $\sqrt{ }$ & - & - & - & $\sqrt{ }$ & - & $\sqrt{ }$ \\
\hline $\begin{array}{l}\text { Said, Alam, } \\
\text { Mohamed, \& } \\
\text { Rafidi (2017) }\end{array}$ & Yes & $\sqrt{ }$ & - & $\sqrt{ }$ & - & $\sqrt{ }$ & $\sqrt{ }$ & $\sqrt{ }$ \\
\hline $\begin{array}{l}\text { Chang, Wilding, \& } \\
\text { Shin (2017) }\end{array}$ & Yes & $\sqrt{ }$ & $\sqrt{ }$ & $\sqrt{ }$ & $\sqrt{ }$ & $\sqrt{ }$ & $\sqrt{ }$ & - \\
\hline Said et al (2017) & Yes & $\sqrt{ }$ & $\sqrt{ }$ & $\sqrt{ }$ & - & $\sqrt{ }$ & - & - \\
\hline $\begin{array}{l}\text { Anuar, Saiful, \& } \\
\text { Puteh (2017) }\end{array}$ & No & $\sqrt{ }$ & - & $\sqrt{ }$ & - & - & $\sqrt{ }$ & $\sqrt{ }$ \\
\hline
\end{tabular}


Table 3: Continued

\begin{tabular}{|c|c|c|c|c|c|c|c|c|}
\hline Author & Instrument & Aims & $\begin{array}{c}\text { Instrument } \\
\text { tested }\end{array}$ & Sample & Ethics & $\begin{array}{l}\text { Result } \\
\text { Clarity }\end{array}$ & $\begin{array}{c}\text { Practical } \\
\text { Implication }\end{array}$ & Conclusion \\
\hline $\begin{array}{l}\text { Chaudary, Priya, } \\
\text { \& Phoolka (2017) }\end{array}$ & Yes & $\sqrt{ }$ & $\sqrt{ }$ & $\sqrt{ }$ & - & $\sqrt{ }$ & $\sqrt{ }$ & $\sqrt{ }$ \\
\hline $\begin{array}{l}\text { Park \& Lewis } \\
(2018)\end{array}$ & Yes & $\sqrt{ }$ & $\sqrt{ }$ & $\sqrt{ }$ & $\sqrt{ }$ & $\sqrt{ }$ & - & $\sqrt{ }$ \\
\hline $\begin{array}{l}\text { Anugerah, } \\
\text { Abdillah,\&Anita } \\
(2018)\end{array}$ & No & $\sqrt{ }$ & - & - & - & $\sqrt{ }$ & $\sqrt{ }$ & $\sqrt{ }$ \\
\hline $\begin{array}{l}\text { Latan et al. } \\
(2018)\end{array}$ & Yes & $\sqrt{ }$ & - & $\sqrt{ }$ & $\sqrt{ }$ & $\sqrt{ }$ & $\sqrt{ }$ & $\sqrt{ }$ \\
\hline $\begin{array}{l}\text { Latan, Ringle, \& } \\
\text { Jabbour (2018) }\end{array}$ & Yes & $\sqrt{ }$ & $\sqrt{ }$ & $\sqrt{ }$ & $\sqrt{ }$ & $\sqrt{ }$ & $\sqrt{ }$ & $\sqrt{ }$ \\
\hline $\begin{array}{l}\text { Dhamija \& Rai } \\
(2018)\end{array}$ & Yes & $\sqrt{ }$ & - & $\sqrt{ }$ & - & $\sqrt{ }$ & $\sqrt{ }$ & - \\
\hline $\begin{array}{l}\text { Kyu Wang, Fu, \& } \\
\text { Yang (2018) }\end{array}$ & No & $\sqrt{ }$ & $\sqrt{ }$ & $\sqrt{ }$ & - & $\sqrt{ }$ & - & $\sqrt{ }$ \\
\hline $\begin{array}{l}\text { Nayır, Rehg, \& } \\
\text { Asa (2018) }\end{array}$ & No & $\sqrt{ }$ & - & $\sqrt{ }$ & - & $\sqrt{ }$ & $\sqrt{ }$ & - \\
\hline $\begin{array}{l}\text { Anuar et al. } \\
(2019)\end{array}$ & Yes & $\sqrt{ }$ & $\sqrt{ }$ & $\sqrt{ }$ & - & $\sqrt{ }$ & - & $\sqrt{ }$ \\
\hline $\begin{array}{l}\text { Cheng, Bai, \& } \\
\text { Yang (2019) }\end{array}$ & yes & $\sqrt{ }$ & $\sqrt{ }$ & $\sqrt{ }$ & - & $\sqrt{ }$ & $\sqrt{ }$ & $\sqrt{ }$ \\
\hline $\begin{array}{l}\text { Latan, Jabbour, \& } \\
\text { Jabbour (2019) }\end{array}$ & yes & $\sqrt{ }$ & $\sqrt{ }$ & $\sqrt{ }$ & $\sqrt{ }$ & $\sqrt{ }$ & $\sqrt{ }$ & $\sqrt{ }$ \\
\hline $\begin{array}{l}\text { Latan, Jabbour, \& } \\
\text { Jabbour (2019) }\end{array}$ & yes & $\sqrt{ }$ & - & $\sqrt{ }$ & $\sqrt{ }$ & $\sqrt{ }$ & $\sqrt{ }$ & $\sqrt{ }$ \\
\hline
\end{tabular}

Source: Quantitative studies critical appraisal checklist (adapted from Bowling, 2009)

In organizational behavior and the HR area, integrative reviews can be used as tools for evaluating the strength of the scientific evidence, identifying gaps in current research as well as identifying the need for future research. In a thoroughly review the integrative review can be used to identify a theoretical or conceptual framework and exploring which research methods have been used successfully. As it is been stated previously that by examining specific culture, like the collectivist culture the extraction of whistleblowing effect on HR and OB can be identified in terms of the antecedents, determinants as well as other outcome variables that could be potentially important to look at for the future studies effort.

As the review predominantly focuses on the Asia countries, the identification of factors that enable the whistleblowing in this culture could be applied to other collectivist countries. There is no doubt that scholars agree that fraud is the key issue in a typical collectivist organization. Based on the review results, the dominant discussed aspect is related to someone's intention to do whistleblowing in an organization whether internal, external or anonymous whistleblowing is influenced by numerous factors. Park et al. $(2005 ; 2008)$ explain that nationality and cultural orientation are the main factors for someone in conducting whistleblowing. This becomes an important aspect because, in a collectivist culture, issues related to whistleblowing or fraud are sensitive issues that generally give rise to biased responses in the community. Someone who reports fraud in an organization can be considered a hero but also a traitor at the same time. Another dimension in the whistleblower phenomenon is that positive practices of whistleblowing may be related to the cultural dimension (Berry, 2004). The culture that develops in an organization can be in the form of ethical culture (ethical culture) or vice versa in the form of unethical culture (Tavakoli, Keenan, \& Cranjak-Karanovic, 2003). 
The reviews found that in Malaysia (Jamaliah et al., 2017) and Thailand (Thongmaaerut, 2012) which place that subjective norms resulted from the individual values play significant role in promoting whistleblowing intentions. A key issue in promoting courage in being a whistleblower is resulted from the individual religiosity and value in avoiding seeing and doing bad acts. A person may become whistleblower if they believe that fraud or wrongdoing may harm the organization. The review found that in collectivist culture this could be a successful determinant in promoting fraud actions.

Among all the papers reviewed, there is a tendency that the study is focused on the ethical issues as well as the building of organizational culture in a sense to establish whistleblowing intentions and organizational climate. As what Lee and Chae (2018) stated that disclosure is important in maintaining ethical climate in organization. Organizations should be able to create an organizational culture that can accommodate and bring up the habit of whistleblowing for fraud that occurs in the organization, as lessons in the shareholders relationship which is accommodate the supervision of information disclosure of listed firms that could improve information transparency (Yin \& Zhang, 2019). This certainly requires the support of the leader in the organization. There is an important role of a leader in shaping culture in uncovering any fraud that exists in the organization. Ethical leaders provide support and protection for subordinates who report wrongdoing or fraud. Subordinates need more motivation and courage to report unusual problems in the organization. The concept of ethical leadership was put forward by Brown et al. (2005) which is a combination of transactional leadership and transformational leadership. Brown et al. (2005) stated ethical leader displays ethical behavior, considered as a role model by subordinates and an ethical leader is not only ethical himself but also support subordinates by creating an appropriate norm, practices, and systems. Hwang et al. (2008) explain that morality and personal relationships are important factors in China in the existing disclosure behavior of fraud; that tendency also proved to be effective in India that type of trust in bank sector is important in maintaining relationship with customers (Polturi \& Polturi, 2017).

In relation to the HR and OB literature, whistleblowing is often associated with the emergence of a person's dissatisfaction with various matters in the organization. Theory of Planned Behavior (TPB) which describes a person's commitment that consists of 3 main factors namely subjective norms, attitude and perceived behavioral control are seen to be the most important factor in whistleblowing intention behavior (Park \& Blenkinsopp, 2009; Trongmateerut et al., 2013).

\section{Conclusions}

From the sociological perspectives, looking at the impact of high context culture on the organizational performance could be lensed from the deontological theory which views an action as an act of good value because the action is carried out based on one's obligations (Legge, 1999). Obligations of a person in this matter can be in the form of obligations towards the organization where he works and obligations to the community. Thus, a whistleblower has a dilemma whether he will prioritize obligations to his organization or obligations to society. The whistleblower's ethical dilemmas and conflicts become even greater when the perpetrators of the deviations are his superiors or close associates, compared to if the perpetrators of the deviations are people who are not well known. Moreover, the deontological theory explains that telling the truth is an obligation and an ethical act and also stressed on whether or not an ethical action is seen from whether the action can achieve the desired goal or not. Whether good or bad the goals referred to here can be either for themselves, both for the organization or for the community (Pops, 2019).

In logical terms, ethical culture in the organization is built in order to create ethical behavior in the organization that encourages the emergence of whistleblowers compared to the formal policies and procedures of an organization regarding whistleblowing. This review reveals that nationality and culture is one of the most important factor to someone doing whistleblowing as an act to disclosing wrongdoing action. Future research should use different methods with larger sample in the topic of whistleblowing in collectivist culture. Limitation to this review were the exclusion of articles published prior to 2003 and limited to several database using keywords identification. Most of articled not included predefined keywords. Because of this latter exclusion, insight into whistleblowing in collectivist culture remain limited.

\section{References}

Ab Ghani, N., Galbreath, J., \& Evans, R. (2011). Predicting whistleblowing intention among supervisors in Malaysia. In: Annual Summit on Business and Entrepreneurial Studies (ASBES 2011) Proceeding.

ACFE. (2019). Report to the Nations on Occupational Fraud and Abuse, 2019 Global Fraud Study. Austin, TX: Association of Certified Fraud Examiner.

Agnihotri, A., \& Bhattacharya, S. (2015). Whistleblowing policy disclosure: evidence from an Indian emerging market. Corporate Governance, 15(5), 678-692. https://doi.org/10.1108/CG-052014-0057

Ahmad, S. A., Ismail, I. S., Azmi, N. A., \& Zakaria, N. B. (2014). Methodological Issues in Whistle-blowing Intentions Research: Addressing the Social Desirability Bias and Order Effect Bias. Procedia-Social and Behavioral Sciences, 145, 204-210. https://doi.org/10.1016/j.sbspro.2014.06.028

Ahmad, S. A., Yunos, R. M., Ahmad, R. A. R., \& Sanusi, Z. M. (2014). Whistleblowing Behaviour: The Influence of Ethical Climates Theory. Procedia - Social and Behavioral Sciences, 164(August), 445-450. https://doi.org/10.1016/j. sbspro.2014.11.101 
Anuar, N., Saiful, A. A., \& Puteh, S. (2017). Whistle blowing intentions - evidence from Malaysian PLC. International Journal of Law and Management, . https://doi.org/https://doi. org/10.1108/IJLMA-04-2017-0096

Anuar, N., Saiful, A. A., \& Puteh, S. (2019). To whistle or not to whistle? Determinants and consequences. Journal of Financial Crime. https://doi.org/https://doi.org/10.1108/JFC-10-20170090

Anugerah, R., Abdillah, M. R., \& Anita, R. (2019). Authentic leadership and internal whistleblowing intention: The mediating role of psychological safety. Journal of Financial Crime, 26(2), 556-567. https://doi.org/10.1108/JFC-04-2018-0045

Bennett, C., Khangura, S., Brehaut, J. C., Graham,I. D., Moher, D., Potter, B. K., \& Grimshaw,J. M. (2011). Reporting guidelines for survey research: An analysis of published guidance and reporting practices. Plos Medicine, 8(8). DOI: 10.1371/journal. pmed.1001069

Berry, B. (2004). Organizational culture: A framework and strategies for facilitating employee whistleblowing. Employee Responsibilities and Rights Journal, 16(1), 1-11.

Beyea, S. C., \& Nicoll, L.H. (1998) Writing an Integrative Review. AORN Journal, 67, 877-880. http://dx.doi.org/10.1016/S00012092(06)62653-7

Bhal, K. T., \& Dadhich, A. (2011). Impact of Ethical Leadership and Leader-Member Exchange on Whistle Blowing: The Moderating Impact of the Moral Intensity of the Issue. Journal of Business Ethics, 103(3), 485-496. https://doi.org/10.1007/ s10551-011-0876-Z

Brennan, N. H., \& Kelly, J. (2007). A Study of Whistleblowing Among Trainee Auditors. British Accounting Review, 39(1), $61-87$

Brown, M. E., Trevino, L. K., \& Harrison, D. A. (2005). Ethical leadership: A social learning perspective for construct developmentand testing. Organizational Behavior and Human Decision Processes, 97, 117-134.

Bowling, A. (2009). Research methods in health:Investigating health and health services. Maidenhead, UK: Open University Press.

Critical Appraisal Skills Programme (CASP). (2014). CASP checklists (qualitative). Oxford, England. Retrieved from http://www.casp-uk. net/\#!casp-tools-checklists/c18f8

Chang, Y., Wilding, M., \& Shin, M. C. (2017). Determinants of Whistleblowing Intention: Evidence from the South Korean Government. Public Performance and Management Review, 40(4), 676-700. https://doi.org/10.1080/15309576.2017.1318 761

Chaudary, N. S., Priya, G. K., \& Phoolka, S. (2017). A study of whistle-blowing intentions of teachers working in higher education sector. International Journal of Law and Management. https://doi.org/https://doi.org/10.1108/IJLMA-10-2017-0253

Cheng, J., Bai, H., \& Yang, X. (2019). Ethical Leadership and Internal Whistleblowing: A Mediated Moderation Model. Journal of Business Ethics, 155(1), 115-130. https://doi. org/10.1007/s10551-017-3517-3
Cheng, X., Karim, K. E., \& Lin, K. J. (2015). A cross-cultural comparison of whistleblowing perceptions. International Journal of Management and Decision Making, 14(1), 15-31.

Chiu, R. K. (2003). Ethical Judgment and Whistleblowing Intention: Examining the Moderating Role of Locus of Control. Journal of Business Ethics, 43(1-2), 65-74. https:// doi.org/10.1023/A:1022911215204

Chordiya, R., Sabharwal, M., Relly, J. E., \& Berman, E. M. (2019). Organizational protection for whistleblowers: a cross-national study. Public Management Review, 22(4), 527-552. https://doi. org/10.1080/14719037.2019.1599058

D'Cruz, P., \& Bjørkelo, B. (2016). Sociocultural dynamics in whistleblowing: insights from India. Asia-Pacific Journal of Business Administration, 8(2), 143-162. https://doi. org/10.1108/APJBA-07-2015-0061

Dhamija, S., \& Rai, S. (2017). Role of retaliation and value orientation in whistleblowing intentions. Asian Journal of Business Ethics, 7, 37-52. https://doi.org/10.1007/s13520-0170078-6

Erkmen, T., Çalişkan, A. Ö., \& Esen, E. (2014). An empirical research about whistleblowing behavior in accounting context. Journal of Accounting and Organizational Change, 10(2), 229-243. https://doi.org/10.1108/JAOC-03-2012-0028

Hwang, D., Staley, B., Chen, Y. Te, \& Lan, J. S. (2008). Confucian culture and whistle-blowing by professional accountants: An exploratory study. Managerial Auditing Journal, 23(5), 504526. https://doi.org/10.1108/02686900810875316

Kyu Wang, T., Fu, K. J., \& Yang, K. (2018). Do Good Workplace Relationships Encourage Employee Whistle-Blowing? Public Performance and Management Review, 41(4), 768-789. https:// doi.org/10.1080/15309576.2018.1464935

Latan, H., Jabbour, C. J., \& Jabbour, A. B. L. S. (2018). 'Whistleblowing Triangle': Framework and Empirical Evidence. Journal of Business Ethics, 160(1), 1-16. https://doi. org/10.1007/s10551-018-3862-x

Latan, H., Jabbour, C. J. C, \& Jabbour, A. B. L. S. (2019a). Ethical Awareness, Ethical Judgment and Whistleblowing: A Moderated Mediation Analysis. Journal of Business Ethics, 155(1), 289-304. https://doi.org/10.1007/s10551017-3534-2

Latan, H., Jabbour, C. J. C, \& Jabbour, A. B. L. S. (2019b). To Blow or Not to Blow the Whistle: The Role of Rationalization in the Perceived Seriousness of Threats and Wrongdoing. Journal of Business Ethics, (0123456789). https://doi.org/10.1007/ s10551-019-04287-5

Latan, H., Ringle, C. M., \& Jabbour, C. J. C. (2018). Whistleblowing intentions among public accountants in indonesia: Testing for the moderation effects. Journal of Business Ethics, 152(2), 573-588. https://doi.org/10.1007/s10551-016-3318-0

Lee, A., \& Chae, S. J. (2018). The effect of management disclosure and analysis on the stock crash risk: Evidence from Korea. Journal of Asian Finance, Economics, and Business, 5(4), 67-72. http://doi.org/10.13106/jafeb.2018.vol5. no4.67 
Legge, K. (1999). The morality of HRM. Human Resource Management: Critical Perspectives on Business and Management, 3, 357-73.

Liu, S. M., Liao, J. Q., \& Wei, H. (2015). Authentic Leadership and Whistleblowing: Mediating Roles of Psychological Safety and Personal Identification. Journal of Business Ethics, 131(1), 107-119. https://doi.org/10.1007/s10551-014-2271-z

Lukacs, E., Cristache, N., Nicolai, M., \&Stoica, M. (2012). Corporate loyalty versus whistleblowing: an ethical challenge in HRM. Business e Leadership, 1, 55-66.

Mesmer-Magnus, J. R., \& Viswesvaran, C. (2005). Whistleblowing in Organization: An Examination of Correlates of Whistleblowing Intentions, Actions, and Retaliation. Journal of Business Ethics. 62: 277-297. https:// doi.org/10.1007/s10551-005-0849-1

Miceli, M. P., Near, J. P., \& Dworkin, T. M. (2008). Whistle blowingin organizations. New York, NY: Routledge.

Nayir, D. Z., \& Herzig, C. (2012). Value Orientations as Determinants of Preference for External and Anonymous Whistleblowing. Journal of Business Ethics, 107(2), 197-213. https://doi.org/10.1007/s10551-011-1033-4

Nayır, D. Z., Rehg, M. T., \& Asa, Y. (2018). Influence of Ethical Position on Whistleblowing Behaviour: Do Preferred Channels in Private and Public Sectors Differ? Journal of Business Ethics, 149(1), 147-167. https://doi.org/10.1007/ s10551-016-3035-8

Nurhidayat, I., \& Kusumasari, B. (2018). Strengthening the effectiveness of whistleblowing system A study for the implementation of anti-corruption policy in Indonesia. Journal of Financial Crime, 25(1), 140-154. https://doi.org/10.1108/ JFC-11-2016-0069

Park, H., \& Blenkinsopp, J. (2009). Whistleblowing as planned behavior - A survey of south korean police officers. Journal of Business Ethics, 85(4), 545-556. https://doi.org/10.1007/ s10551-008-9788-y

Park, H., Blenkinsopp, J., Oktem, M. K., \& Omurgonulsen, U. (2008). Cultural orientation and attitudes toward different forms of whistleblowing: A comparison of South Korea, Turkey, and the U.K. Journal of Business Ethics, 82(4), 929-939. https:// doi.org/10.1007/s10551-007-9603-1

Park, H., \& Lewis, D. (2018). The negative health effects of external whistleblowing: A study of some key factors. Social Science Journal, 55(4), 387-395. https://doi.org/10.1016/j. soscij.2018.04.002

Park, H., Rehg, M. T., \& Lee, D. (2005). The influence of confucian ethics and collectivism on whistleblowing intentions: A study of South Korean public employees. Journal of Business Ethics, 58(4), 387-403. https://doi. org/10.1007/s10551-004-5366-0

Potluri, R. M., \& Potluri, L. S. (2017). An Exploratory Treatise on Jay-customers Behavior in the Banking Industry in India: A Dyadic Perspective. Journal of Asian Finance, Economics and Business, 4(4), 79-86. http://dx.doi.org/10.13106/ jafeb.2017.vol4.no4.79
Pops, G. M. (2019). A teleological approach to administrative ethics. In: Handbook of administrative ethics (pp. 221-232). New York, NY: Routledge.

Rachagan, S., \& Kuppusamy, K. (2013). Encouraging Whistle Blowing to Improve Corporate Governance? A Malaysian Initiative. Journal of Business Ethics, 115(2), 367-382. https:// doi.org/10.1007/s10551-012-1402-7

Robinson, S. N., Robertson, J. C., \& Curtis, M. B. (2012). The effects of contextual and wrongdoing attributes on organizational employees' whistleblowing intentions following fraud. Journal of Business Ethics, 106(2), 213-227.

Said, J., Alam, M. M., Mohamed, D. I. B., \& Rafidi, M. (2017). Does job satisfaction, fair treatment, and cooperativeness influence the whistleblowing practice in Malaysian Government linked companies? Asia-Pacific Journal of Business Administration, 9(3), 220-231. https://doi.org/10.1108/APJBA-06-2017-0053

Suyatno, B., Armstrong, A., \& Thomas, K. (2017). Designing whistleblowing policy and regulations for high-context cultures: a case study in Indonesia. In: Perspectives on Philosophy of Management and Business Ethics (pp. 197-223). Cham, Switzerland: Springer.

Syamsuddin. (2017). The government whistleblowers in generating audit quality (a survey on provincial audit boards in South, Central, and West Sulawesi, Indonesia). International Journal of Law and Management, 59(6), 1046-1058. https://doi. org/10.1108/ijlma-08-2016-0069

Tavakoli, A. A., Keenan, J. P., \& Cranjak-Karanovic, B. (2003). Culture and whistleblowing an empirical study of Croatian and United States managers utilizing Hofstede's cultural dimensions. Journal of Business Ethics, 43(1-2), 49-64.

Trongmateerut, P., \& Sweeney, J. T. (2013). The Influence of Subjective Norms on Whistle-Blowing: A Cross-Cultural Investigation. Journal of Business Ethics, 112(3), 437-451. https://doi.org/10.1007/s10551-012-1270-1

Torraco, R. J. (2005). Writing integrative literature reviews: Guidelines and examples. Human Resource Development Review, 4(3), 356-367.

VomBrocke, J., Simons, A., Niehaves, B., Riemer, K., Plattfaut, R., \& Cleven, A. (2009, June). Reconstructing the giant: on the importance of rigour in documenting the literature search process. In: Ecis (Vol. 9, pp. 2206-2217).

Yin, H., \& Zhang, R. (2019). The Nature of Controlling Shareholders, Political Background and Corporate AntiCorruption Practice Disclosure. Journal of Asian Finance, Economics and Business, 6(1), 47-58. http://doi.org/10.13106/ jafeb.2019.vol6.no1.47

Zhang, J., Chiu, R., \& Wei, L. (2009a). Decision-making process of internal whistleblowing behavior in China: Empirical evidence and implications. Journal of Business Ethics, 88(SUPPL. 1), 25-41. https://doi.org/10.1007/s10551-008-9831-z

Zhang,J., Chiu, R., \&Wei,L.Q.(2009b). Onwhistleblowingjudgment and intention: The roles of positive mood and organizational ethical culture. Journal of Managerial Psychology, 24(7), 627-649. https://doi.org/10.1108/02683940910989020 